\title{
Identification and Analysis of Problems in Selected European Historic Gardens during the COVID-19 Pandemic
}

\author{
Katarzyna Hodor ${ }^{1, *(D)}$, Łukasz Przybylak ${ }^{2}$, Jacek Kuśmierski ${ }^{3}{ }^{\circledR}$ and Magdalena Wilkosz-Mamcarczyk $^{4}$ \\ 1 Chair of Landscape Architecture, Faculty of Architecture, Cracow University of Technology CUT, \\ Warszawska 24, 31-155 Kraków, Poland \\ 2 European Route of Historic Gardens, Plaça de la Vila 1, 17310 Lloret del Mar, Spain; \\ vicepresident@europeanhistoricgardens.eu \\ 3 Museum of King John III's Palace at Wilanów, Stanisława Kostki Potockiego 10/16, 02-958 Warsaw, Poland; \\ jkusmierski@muzeum-wilanow.pl \\ 4 Department of Land Management and Landscape Architecture, \\ Faculty of Environmental Engineering and Land Surveying, University of Agriculture in Kraków, \\ Balicka 253 c, 30-198 Kraków, Poland; magdalena.wilkosz-mamcarczyk@urk.edu.pl \\ * Correspondence: khodor@pk.edu.pl; Tel.: +48-608396220
}

Citation: Hodor, K.; Przybylak, Ł.; Kuśmierski, J.; Wilkosz-Mamcarczyk, M. Identification and Analysis of Problems in Selected European Historic Gardens during the COVID-19 Pandemic. Sustainability 2021, 13, 1332. https://doi.org/ $10.3390 /$ su13031332

Received: 19 December 2020

Accepted: 25 January 2021

Published: 27 January 2021

Publisher's Note: MDPI stays neutral with regard to jurisdictional claims in published maps and institutional affiliations.

Copyright: (c) 2021 by the authors. Licensee MDPI, Basel, Switzerland. This article is an open access article distributed under the terms and conditions of the Creative Commons Attribution (CC BY) license (https:// creativecommons.org/licenses/by/ $4.0 /)$.

\begin{abstract}
The paper is based on a survey and investigates the functioning of historic gardens during the pandemic. The authors collected and analysed information on the impact of the pandemic on the behaviour of visitors, maintenance, and condition of cultural heritage assets, European historic gardens. Four aspects were considered particularly carefully: the situation of gardens during the COVID-19 pandemic, maintenance and care in gardens, virtual activity and communication, and financial consequences. The authors determined the conditions of the gardens and the problems they faced based on a survey completed by 23 managers of 31 historic gardens from June to August 2020 and then proposed a diagnosis. The paper presents the survey results. In general, visitor volumes tended to drop in 2020, which significantly affected gardens' financial standing and contributed to workforce reductions. The garden condition and treatments were affected, as well. Reduced visitor volumes resulted in positive environmental changes. Among them were ecological succession, the stability of landscaped plants, increase in vegetation, improved biodiversity in the ground cover, and enhanced animal presence. Additional safety measures were implemented after the gardens were reopened to the public during the pandemic, mostly social distancing, and obligatory face masks. Less than half of the gardens had contingency plans, and $25 \%$ of the respondents were working to develop one. The analyses provided foundations to start working on a universal emergency strategy similar to procedures used for years for permanent collections at museums. Note that, being open public spaces and live museums, historic gardens were the first places reopened after the lockdown. Recommendations based on the study can contribute to the future safe functioning of historic gardens in other similar crises. The guidelines offer instructions, advice, and recommendations that form foundations of the development of a universal management model facilitating the preservation of historic gardens in good condition while exploiting their ecological potential.
\end{abstract}

Keywords: COVID-19; historic parks; historic gardens; landscape architecture; cultural heritage; green cultural heritage; green area

\section{Introduction}

Today, the term 'historical object' applies to every object important for the cultural heritage and development of culture because of its historical, scientific, or artistic value [1] The category includes historic gardens, which were appreciated numerous times by many international organisations, also by being included on the UNESCO World Heritage List [2] Moreover, the 1964 Venice Charter defines a historic monument much more broadly than as just an individual architectural work and includes a rural or urban setting as well. The 
1981 Florence Charter outlines procedures and describes protection of historic gardens. It defines the historic garden as 'an architectural and horticultural composition of interest to the public from the historical or artistic point of view' [3]. It points out that a historic garden is an architectural composition but also a living vegetal fabric and proposes to consider it a natural monument and apply the principles of the Venice Charter to historic gardens [4]. Many European countries became interested in monument protection in the 19th century. France established the Commission of Historic Monuments (Commission des Monuments Historiques), the United Kingdom started The National Trust, and Belgium, the Royal Committee for Monuments and Sites (Commission Royale des Monuments et Sites). Changes in the perception of historic green sites that commenced in the 19th century led to the intentional protection of the gardens [5].

Historic gardens were first studied in the 16th century in treaties on the construction and maintenance of gardens. The art of garden design and care was considered science in the 18th century [6]. Today, historic gardens are appreciated for their social, aesthetic, environmental, cultural, architectural, and perceptual qualities. Research on historic gardens involves analysis of the landscape and its complexity combined with landscape valuation to help users realise the import of heritage they represent [7].

The investigated objects-historic gardens in Europe-have clear aesthetic, natural, and cultural qualities. Despite differences in the scale, origin, and location, they constitute a group of unique heritage assets, increasingly often considered museums. Protection and conservation of historic gardens have been supplemented with the art of remembrance and curation, which resulted in the musealisation of the gardens. It is reflected in various forms of nature and monument protection intended to preserve individual plant specimens, garden compositions, or even whole landscapes in an unaltered form [8,9]. Their conservators employ detailed strategies with protection and conservation plans, directions for restoration, procedures for making them available to the public, and even an exhibition plan. Gardens with works of nature and man became open-air museums [10]. Their growing popularity gave rise to 'garden tourism' as a highly specialised and rather profitable branch of cultural tourism [11]. It is important to appreciate their social and ecological roles in the landscape and their uniqueness related to cultural heritage. Historic gardens are a crucial part of cultural heritage. They remain a memento of the centuries past with their invariable style and character reflecting their times despite changes in urban and rural environments over time [12-14].

Experts focus on so-called process conservation today. It involves regular shaping, maintenance, change management, and resource management in individual time intervals. As regards physical operations, reconstruction of former gardens, in particular, they propose conservation through documentation and preservation of value. The cultural approach to the gardens helps expand the knowledge of history and sources of inspiration for art, religion, and philosophy [15]. The heritage of historic gardens is perceived considering the preservation indicators and its values. Experts look into the historical value, presence of plants from the initial design, historic buildings, and park furniture and small structures. The artistic qualities, garden's design, shape, and colour matter as well [6]. Being a living tissue, historic gardens need to be conserved and their heritage, protected. The care for the gardens, which are also artistic objects, and their conservation is the expression of the culture of our societies $[16,17]$ Otherwise, they may be degraded, and the damage can be irreversible.

Management is a key component of the effort to protect historic gardens as heritage sites. Sufficient funding for historic gardens in the current COVID-19 crisis may contribute to a thriving urban environment in the future. Contact with history and nature promotes the identity of people and their aesthetic experience after a long quarantine. Well-organised museums, historic gardens, and botanic gardens may play an important role in research, education, and environmental protection [18]. Therefore, it is necessary to complement research on historic gardens with methods specific to social sciences, economics, and resource assessment, tourism research, and urban heritage studies $[4,19]$. The current 
COVID-19 epidemic led to crises in many industries [20], also in tourism. Lifestyle, tourist behaviour, and travel preferences changed [21,22]. The slump in international tourism and at the local level [23] affected the functioning of gardens significantly. The usual forms of activity and recreation in gardens were interrupted, which affected the well-being of regular garden users [24]. Some organisations took action (in line with the limitations in place in their respective countries at the time) to develop documents with hints and advice regarding the management of parks and sites so that they could become safe spaces for leisure with nature and in conformity with all necessary safety principles, such as Comité des Parcs et Jardins de France, La Demeure Historique, Greenspace Scotland, or The Fields in Trust.

The COVID-19 outbreak in late 2019 and early 2020 intensified all known groups of management and restoration challenges and merged them into one global factor that affected all garden heritage sites. The scale of the new threat to cultural heritage, including historic gardens, can be compared to the period of 1939-1945 when the global military conflict endangered the future of cultural civilisation assets. The Second World War was a trying time for historic sites. Many cities were destroyed, with parks and gardens along with them $[25,26]$.

This completely new 'super factor' brought to view the need to pay historic gardens the attention similar to the one reserved for works of art and architecture. Museum items are often secured with evacuation procedures for collections $[27,28]$. The buildings often have emergency plans and conservation monitoring systems that keep track of environmental data and help with prevention and rescue activities. They also have systems preventing damage by vandalism, theft, or fire. [29-31]. Historic gardens do not have such precautions. This gigantic emergency-response gap calls for universal procedural models that can be adapted for small sites and large landscape complexes facing a crisis. It should be a set of management practices determined first and foremost by the style and specific character of the garden composition that will help keep it in good condition in the face of a similar crisis. Each institution in charge of a historic garden became a unique case study when the pandemic broke out. Its experience can either be used in a universal management model or as a caution against decisions that could lead to degradation of a monument with time.

\section{Study Area and Objectives}

The analysis focuses on historic gardens situated in Europe. The authors addressed associations of historic gardens and people in charge of individual gardens. The survey was addressed to managers of historic gardens. We followed two tracks to encourage them to complete the questionnaires on an online platform. The first one was to contact the gardens directly (requests sent to the managers, also members of the European Network of Historic Gardens: 31 members from Germany, Georgia, Italy, Poland, Portugal, and Spain). The other way was to post questionnaires to social media and open-access websites (such as the newsletter of the Dutch Castles, Historic Country Houses \& Rural Estates Foundation sKBL (stichting Kastelen Buitenplaasten Landgoederen), ERHG (European Route of Historic Gardens), Landscape Conference in Kraków, and in industry-specific groups on LinkedIn). The survey is estimated to have reached 56 respondents apart from the open-access availability mentioned above.

Survey questionnaires were completed by garden managers from Poland, Germany, the Netherlands, Portugal, Spain, United Kingdom, Sweden, and Italy (Table 1, Figure 1). 
Table 1. List of respondents.

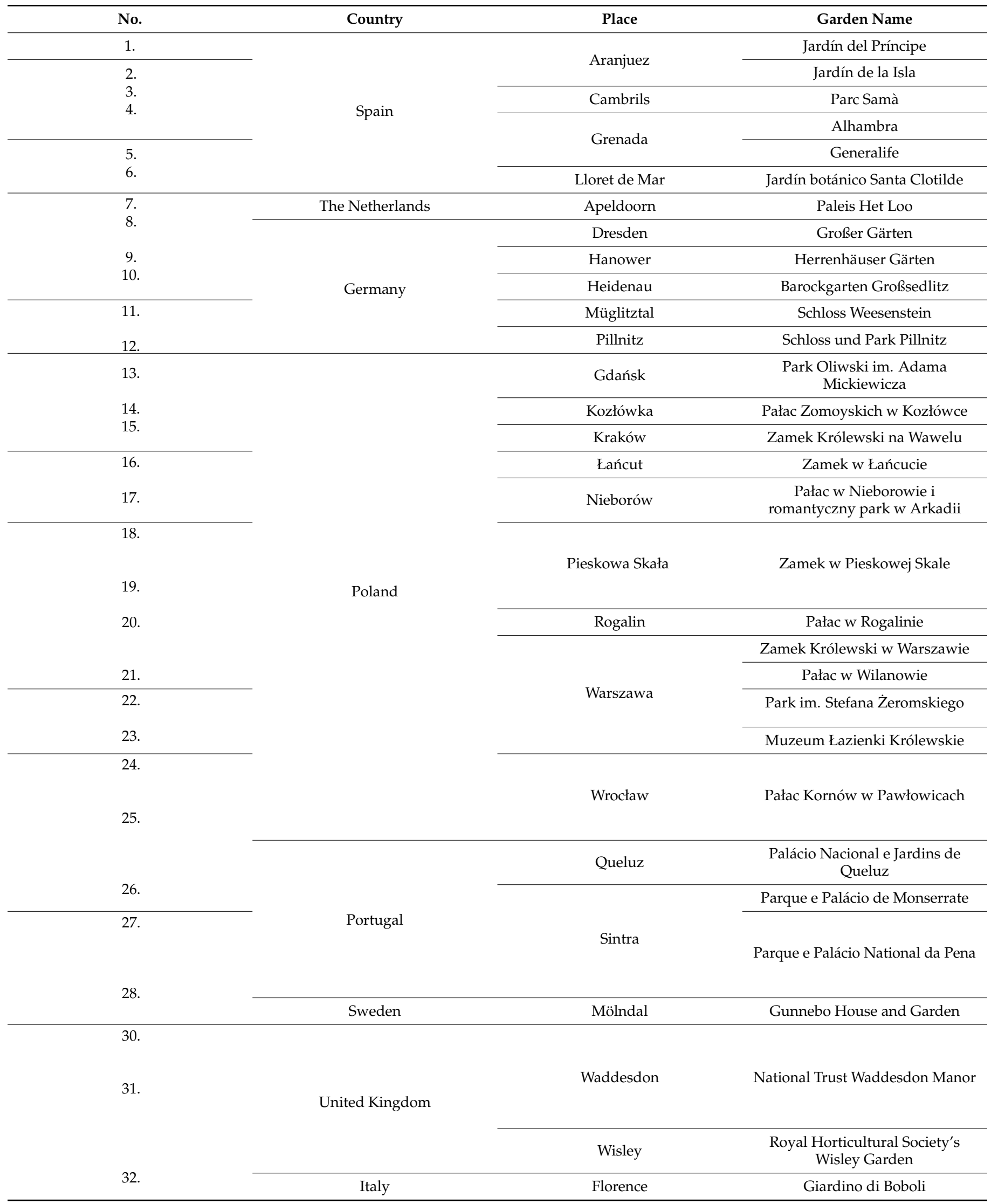




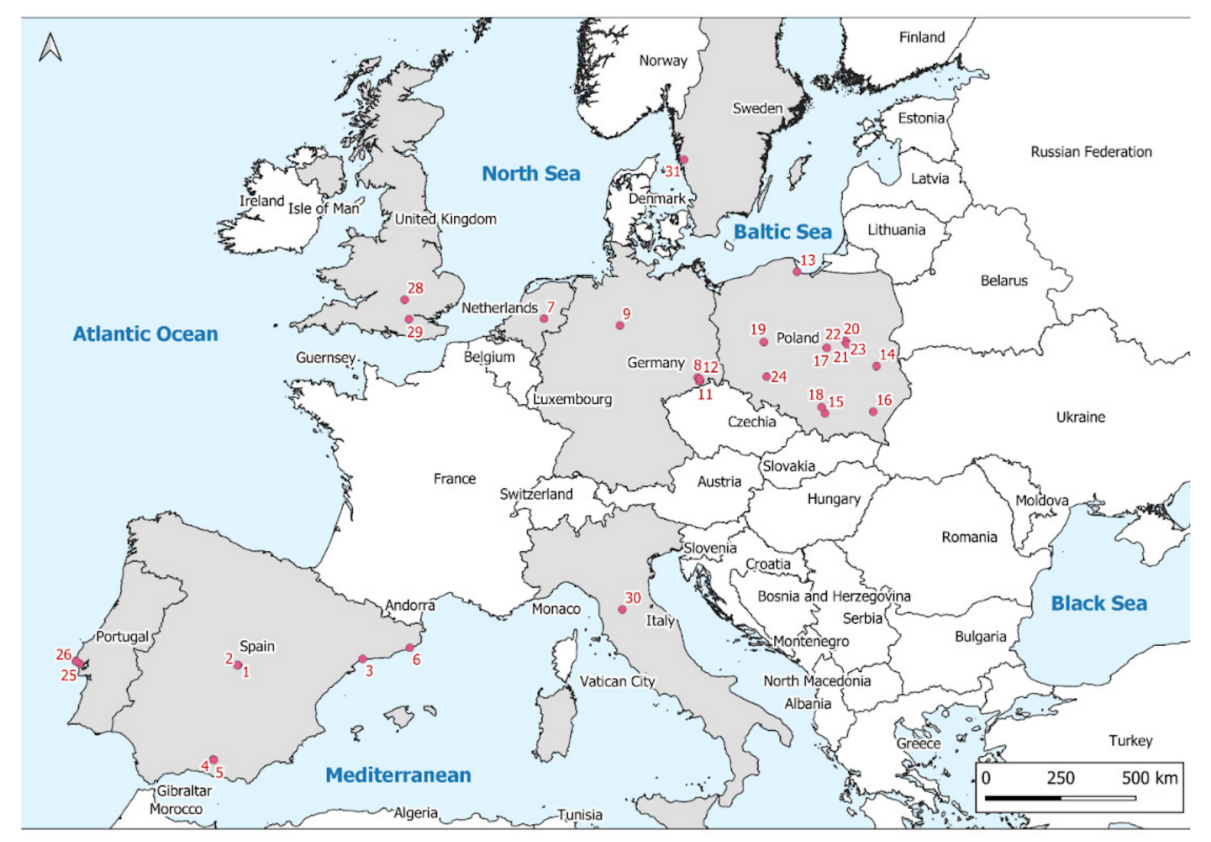

Figure 1. Map of Europe with countries where the participating gardens are located 1. Jardín del Príncipe (UNESCO Aranjuez Cultural Landscape) 2. Jardín de la Isla 3. Parc Samà 4. Alhambra (UNESCO Alhambra, Generalife and Albayzín, Granada), 5. Generalife (UNESCO Alhambra, Generalife and Albayzín, Granada), 6. Jardín botánico Santa Clotilde 7. Paleis Het Loo 8. Großer Gärten 9. Herrenhäuser Gärten 10. Barockgarten Großsedlitz 11. Schloss Weesenstein 12. Schloss und Park Pillnitz 13. Park Oliwski im. Adama Mickiewicza 14. Pałac Zomoyskich w Kozłówce 15. Zamek Królewski na Wawelu (UNESCO Historic Centre of Cracow), 16. Zamek w Łańcucie 17. Pałac w Nieborowie i romantyczny park w Arkadii 18. Zamek w Pieskowej Skale 19. Pałac w Rogalinie 20. Zamek Królewski w Warszawie (UNESCO Historic Centre of Warsaw) 21. Pałac w Wilanowie 22. Park im. Stefana Żeromskiego 23. Muzeum Łazienki Królewskie 24. Pałac Kornów w Pawłowicach 25. Palácio Nacional e Jardins de Queluz 26. Parque e Palácio de Monserrate (UNESCO Cultural Landscape of Sintra) 27. Parque e Palácio National da Pena 28. National Trust Waddesdon Manor 29. Royal Horticultural Society's Wisley Garden 30. Giardino di Boboli (UNESCO Medici Villas and Gardens in Tuscany) 31. Gunnebo House and Garden.

All the participating gardens are protected and listed as national monuments or included on the UNESCO World Heritage List (individually or as part of a site). They represent almost all garden style groups: Islamic with late Medieval components, Medieval, Renaissance, Baroque, Landscape, Romantic, neo-style, and Modernist. The objects of interest are public spaces situated in city centres (8), in cities or towns (2), on the outskirts (10), and in rural areas (11).

This paper aims to present an initial estimate of historic gardens affected by lockdown and the steps they have taken to continue their activity. The research includes the identification and listing of main landscape, financial, and managerial issues in public spaces that are historic gardens. The particular focus was the impact of the COVID-19 pandemic on the preservation, maintenance, and condition of gardens as cultural heritage assets. The responses allowed the authors to develop an outline of recommendations for a universal managerial model that should offer procedural guidelines for if the pandemic continues and other similar emergencies. The authors have based their multifaceted assessment of the influence of the emergency on the management of historic gardens' resources on financial activities, virtual actions, care treatments, and human resources initiatives.

\section{Methodology}

Management challenges that historic gardens face today can be classified into six groups. These are methodological, regulatory, technological, administrative, social, and 
environmental challenges that affect what model of management is implemented in a facility [32]. Although the origins of the challenges are often global, their intensity that determines the condition and maintenance methods for a historic garden, as well as mitigation actions, are evaluated at a much smaller scale, often a region or local environment of an individual garden.

To identify the scale of impact of the COVID-19 pandemic and relevant restrictions on the stability of conservation and social position of historic gardens, questions needed to be based on management methods. The management method is determined by the vertical and horizontal, administrative, and financial structure of a garden. The vertical structure is its measurable geographical reach, topography, and hydrology in the area. The vertical structure includes not only all components of the vegetation but also mobile and immobile garden equipment (including sculptures and fountains). The administrative structure means the mode of ownership, the profile of the institution in charge of the garden, statutory activities based on its resources, and the way the personnel responsible for ongoing maintenance of the garden is managed. Note that the extent of the vertical and horizontal structure should proportionally shape the size of the administrative and financial structures that ensure the maintenance of the existing condition of the garden or its smooth restoration [33].

\section{Survey}

The authors identified aspects of historic garden maintenance and used them to develop a set of issues relevant to the basic information on ongoing care, statutory activity, and administrative and financial circumstances. The palette of questions helped collect basic and detailed data from many facilities on the time and nature of the response of the management and the care, conservation, and marketing activities that followed. The combination of interpretation of general information about components of the horizontal and vertical structures of the gardens and responses to in-depth questions regarding their administrative and financial structures facilitated a thorough and innovative attempt to develop universal conservation guidelines for the maintenance and functioning of European historic gardens and parks in the face of the COVID-19 pandemic.

The survey questionnaire 'Garden heritage in the face of the COVID-19 pandemic' was distributed online from 19 June 2020 to 12 August 2020. It contained four categories of questions: the situation of gardens during the COVID-19 pandemic, maintenance, and care in gardens, virtual activity and communication, financial consequences (Figure 2). The questionnaire consisted of 23 questions. Eleven of them were open-ended questions, and twelve were closed-ended. The latter were single-select and multi-select questions depending on its scope. The respondents could offer a comment on some of them to provide more in-depth insight. Open-ended questions focused on issues where qualitative results were desirable to provide a broader view of the impact of the pandemic on historic gardens.

The general inquiries involved the name of the site, which facilitated a more thorough insight into the character of the garden, especially as regards its vertical structure and the area (in hectares) to represent the scale of its horizontal structure. When combined with information about the number of people involved in routine care, changes in team sizes as a result of the outbreak, and identifiable deterioration of the condition of the garden, the general data helped uncover further relationships. The information demonstrated how varied the participating sites were. The question about a strategic document with maintenance standards or restoration plan for the site was an important one. Being an unforeseen emergency, the COVID-19 pandemic could be a trigger to verify the documents as part of a change management process, for example, through the reduction of teams involved in garden maintenance or limitation of the scope of operations. 


\begin{tabular}{|c|c|}
\hline GENERAL DATA & $\begin{array}{l}\text { SITUATION OF GARDENS DURING THE COVID- } \\
19 \text { PANDEMIC }\end{array}$ \\
\hline Garden area (in hectares) & $\begin{array}{l}\text { Was the garden closed down due to the COVID-19 } \\
\text { pandemic? If yes, specify the date of the closure? }\end{array}$ \\
\hline $\begin{array}{l}\text { Is there a strategy-level document for the } \\
\text { garden with maintenance standards or a } \\
\text { restoration plan? }\end{array}$ & $\begin{array}{l}\text { Has the garden been reopened? If yes, specify the } \\
\text { date of the reopening. }\end{array}$ \\
\hline & $\begin{array}{l}\text { Were there any special safety measures } \\
\text { introduced after the garden was reopened? If yes, } \\
\text { what are they? You may select more than one } \\
\text { response. }\end{array}$ \\
\hline & $\begin{array}{l}\text { Specify the frequency in the garden in the first } \\
\text { and second quarter of } 2018,2019 \text {, and } 2020 .\end{array}$ \\
\hline \multicolumn{2}{|c|}{ MAINTENANCEANDCARE IN GARDENS } \\
\hline \multicolumn{2}{|c|}{$\begin{array}{l}\text { How many gardeners were usually maintaining the garden on a daily basis before the COVID-19 } \\
\text { pandemic? Estimate the value. }\end{array}$} \\
\hline \multicolumn{2}{|c|}{$\begin{array}{l}\text { How many gardeners were maintaining the garden on a daily basis during the COVID-19 pandemic? } \\
\text { Estimate the value. }\end{array}$} \\
\hline \multicolumn{2}{|c|}{$\begin{array}{l}\text { How was the work of the maintenance department organised during the COVID-19 pandemic? You may } \\
\text { select more than one response. }\end{array}$} \\
\hline \multicolumn{2}{|c|}{$\begin{array}{l}\text { Has the change of work organisation during the COVID-19 pandemic harmed the general condition of the } \\
\text { garden? Which tasks were abandoned and which were carried out? List the key works. }\end{array}$} \\
\hline \multicolumn{2}{|c|}{$\begin{array}{l}\text { What actions can be taken to avoid or control the negative impact of a pandemic on the condition of } \\
\qquad \text { gardens? You may select more than one response. }\end{array}$} \\
\hline \multicolumn{2}{|c|}{$\begin{array}{l}\text { Have you noticed any positive environmental changes after the closure, such as a plant succession, } \\
\text { return of wild animals, or improvement of water quality? If yes, what were they? }\end{array}$} \\
\hline \multicolumn{2}{|c|}{ Will the positive environmental changes be preserved? If yes, how they are going to be kept? } \\
\hline \multicolumn{2}{|c|}{ Did you take counsel from other garden management experts during the COVID-19 pandemic? } \\
\hline \multicolumn{2}{|c|}{$\begin{array}{l}\text { How long did it take to develop and implement a contingency maintenance plan after you have received } \\
\qquad \text { a notification to close the garden down? }\end{array}$} \\
\hline VIRTUAL ACTIVITY AND GOMMUNICATION & FINANCIAL CONSEQUENCES \\
\hline $\begin{array}{l}\text { Was the garden involved in virtualactivities } \\
\text { during the COVID- } 19 \text { pandemic? If yes, what } \\
\text { were they? You may select more than one } \\
\text { response. }\end{array}$ & $\begin{array}{l}\text { How has the COVID-19 pandemic affected the } \\
\text { current economic situation of the garden? }\end{array}$ \\
\hline Was garden staff involved in virtual activities? & $\begin{array}{l}\text { How has the COVID-19 pandemic affected the } \\
\text { current economic situation of garden } \\
\text { employees? You may select more than one }\end{array}$ \\
\hline $\begin{array}{l}\text { Did garden employees require training in virtual } \\
\text { activities? }\end{array}$ & response. \\
\hline $\begin{array}{l}\text { Was the garden engaged in other special } \\
\text { activities regarding virtual presence and } \\
\text { communication? If yes, what were they? }\end{array}$ & $\begin{array}{l}\text { Have any additional funds for the garden been } \\
\text { sought because of the COVID- } 19 \text { pandemic? You } \\
\text { may select more than one response. }\end{array}$ \\
\hline
\end{tabular}

Figure 2. A diagram of survey questions.

The next section looked into the situation of the gardens during the pandemic. It focused on whether or not the garden was closed down, when, if at all, it was reopened, and what precautions were implemented. Its goal was to demonstrate the impact of the pandemic on the accessibility of the sites to the public. Visitor number was one of the 
factors illustrating the effects of COVID-19 on the financial situation of historic gardens and their social position. To paint a full picture of changes, the respondents were asked to provide visitor number data for the first and second quarters of 2018, 2019, and 2020. Note that the influence of the epidemic on historic gardens is a long-term phenomenon and will require data for the same quarters of 2021 and 2022. Nevertheless, the data for the 31 sites gave insight into social trends regarding the need to visit historic gardens in the initial period after the restrictions on the use of public spaces were lifted.

The third group of questions concerned maintenance and care in the gardens before and after the outbreak. The key matter was to determine the number of people involved in the everyday care of a garden and changes in human resources after health safety regulations were introduced in the initial phase of the pandemic. One question concerned the way work of the maintenance team was organised during the pandemic to determine the most popular management methods used to limit movement and ensure social distancing.

The respondents were further asked what actions could be taken to avoid or control the negative impact of a pandemic on the condition of the gardens. Its objective was to determine whether it was material or intangible aid that is more important to managers in a crisis. They were also asked whether they consulted other experts in garden management during the COVID-19 pandemic and how long it took to develop and implement a contingency plan after they received a notification to close the garden down. The goal was to check how many of the respondents needed additional professional support and how many acted on their own. The reaction time to the pandemic was investigated as well.

The one before the last section of the questionnaire looked into virtual activities and communication. The respondents were asked whether their facilities undertook such actions, if their employees took part in them, and if there was a need to train them in virtual operations. The questions were intended to determine the participation of historic gardens in the virtual world and whether it required an improvement of digital competencies of the personnel. The last, fifth section of the questionnaire handled financial consequences. The respondents declared the impact of the pandemic on the budgets of their sites, the financial situation of the employees, and whether any additional measures were taken to obtain additional funds to preserve jobs. The objective was to find out whether and to what extent the closure of the gardens affected their financial standing, if the crisis financially hurt the employees, and what corrective actions the managers implemented.

\section{Results}

The responses to the question concerning the date of closure and reopening of the gardens to the public yielded the average duration of the period of about 2.5 months. The knowledge of the period of zero attendance gives some idea of the dynamics of natural succession and general biocoenotic changes in the sites. The closure took place in the first and second quarter of 2020. The visitor number data for the same periods of 2018, 2019, and 2020 yielded general trends in the 'consumption' of gardens (irrespective of the offer of a particular garden) but also an insight into its radical drop due to health restrictions with its far-reaching financial consequences. Complete quarterly data were provided by seven respondents (Santa Clotilde Botanical Garden—Spain, Herrenhausen GardenGermany, Park of Pena-Portugal, Park of Monserrate-Portugal, National Palace Gardens of Queluz-Portugal, Wilanów Palace Gardens-Poland, and the Royal Łazienki-Poland). The non-standard typical schedule of one of the gardens, Wawel Royal Castle (Poland), allowed it to provide data only for second quarters (Figure 3). Five respondents provided aggregate attendance data for 2018 and 2019 and partial data for 2020 (Figure 4). Over half of the respondents failed to provide relevant data. 


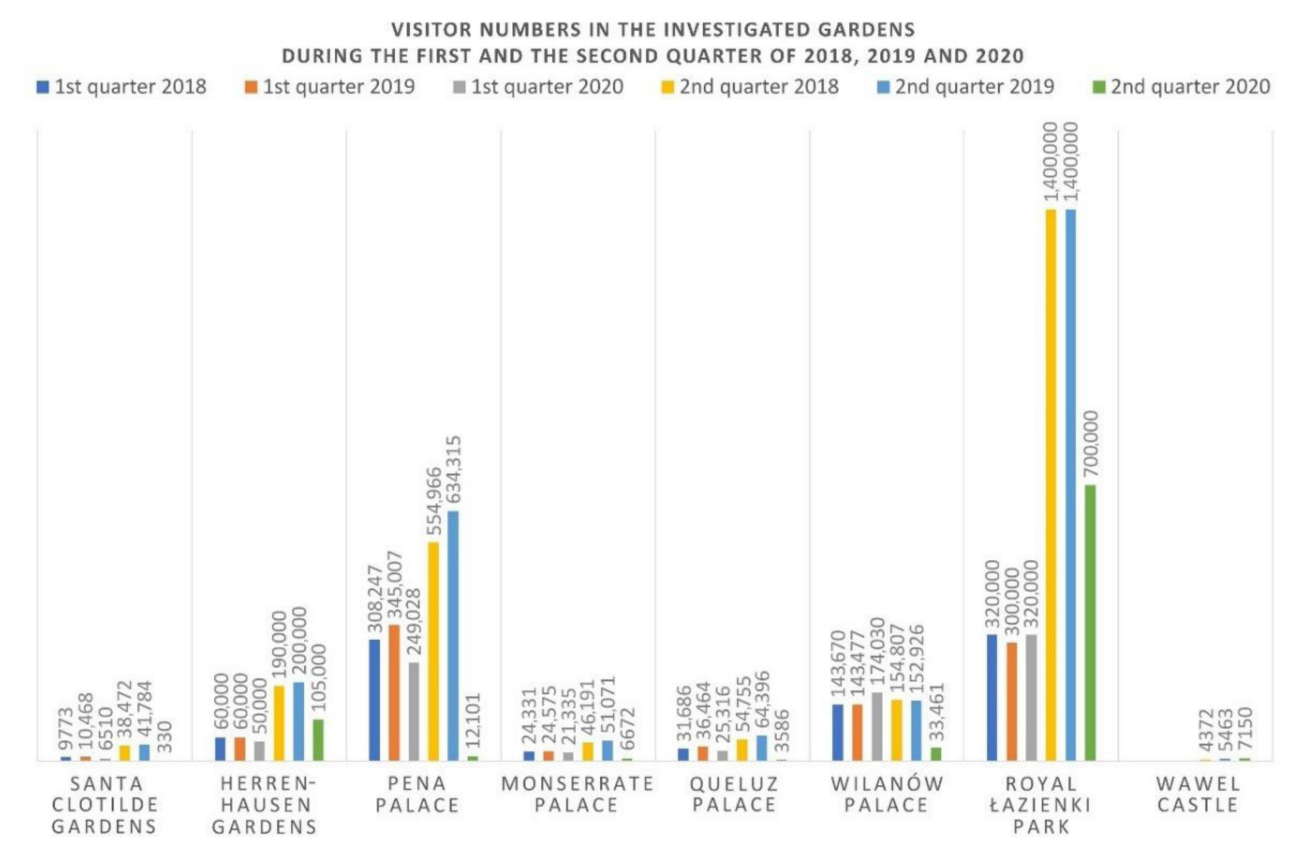

Figure 3. Visitor numbers in the investigated gardens during the first and the second quarter of 2018, 2019 , and 2020.

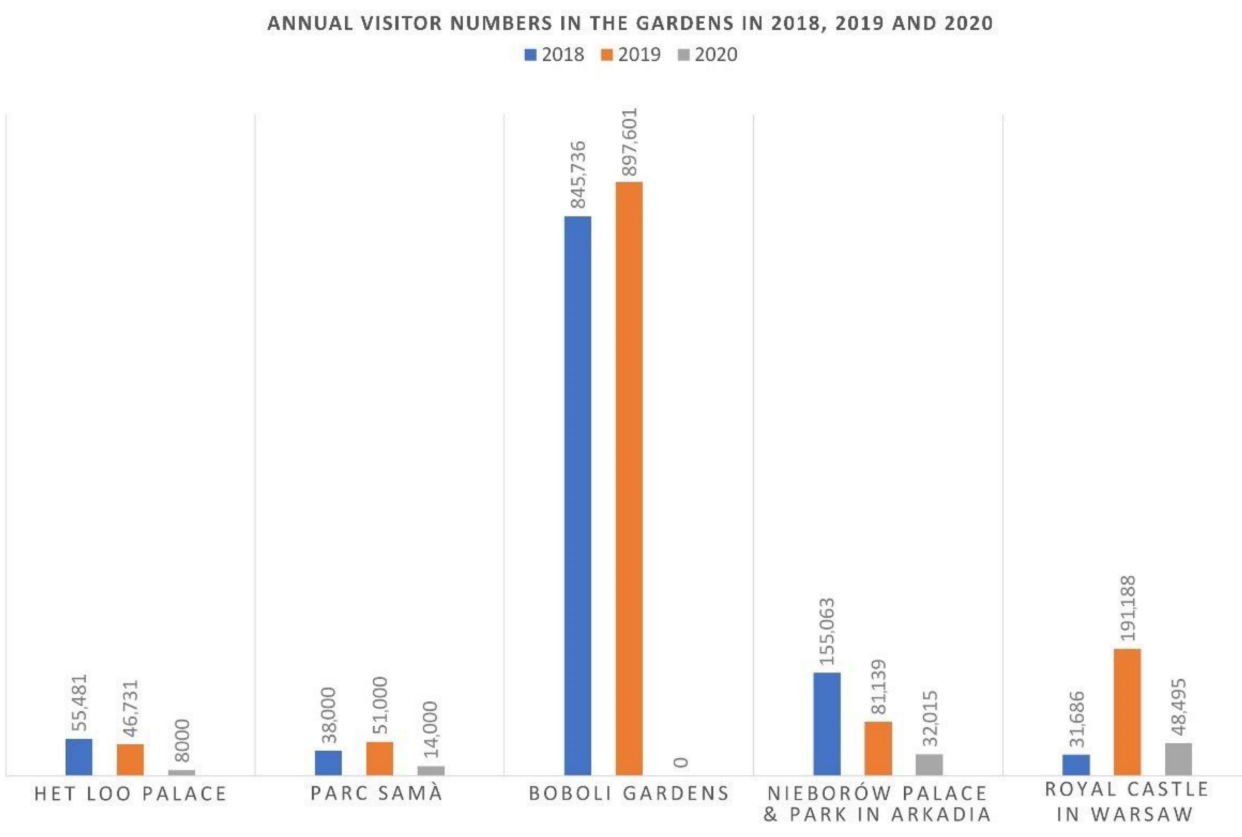

Figure 4. Annual visitor numbers in the gardens in 2018, 2019, and 2020.

The reopening was followed by additional safety measures. The most popular were distancing (25\%) and the obligation to wear masks (19\%). Next were the reduction in the number of visitors allowed $(15 \%)$, shorter opening hours (15\%), and disinfection of benches and other resting places $(12 \%)$. The diverse scales of health restrictions implemented in European countries represented by the respondents were reflected in the attendance changes in the second quarter of 2020. For Central and Eastern European countries, a clear trend was found. The visitor volume went down to $40-50 \%$ of the $2018-2019$ numbers. Respondents from Western Europe provided devastating visitor data for the second quarter of 2020. According to their records, the visitor numbers in West-European tourist destination historic gardens plunged to $0.78-13.06 \%$ of 2019 figures. Such a dramatic decrease in visitor volume paints a morbid picture of the financial situation of sites, the 
primary source of income of which are entrance fees. The consequences are a direct threat to the stability of the garden and the clarity of its historical spatial structure. It also suggests the answer to the question of the financial and personnel impacts of COVID-19. Significant financial losses and employment reductions among those responsible for maintenance will lead to loss of artistic qualities of the garden.

Data on the number of people involved in the everyday care of a garden and changes in human resources after health safety regulations were introduced in the initial phase of the pandemic indicate that $32 \%$ of the gardens maintained complete personnel responsible for ongoing maintenance. The typical solution regarding the size of the team responsible for fieldwork was a reduction to $74-50 \%$ and $49-25 \%$, for the investigated gardens. This change was most often accompanied by a rotational shift scheme or a reduction in daily hours. An alarming, yet widespread approach ( $18 \%$ of the respondents) was to restrict personnel to $25-0 \%$ during the pandemic.

The declared temporary changes at the management level resulted in an evident deterioration of the condition of almost one-fourth of the gardens. The respondents indicated two leading factors when asked about the unfavourable effects of the reduction in the gardening personnel. The first one was unforeseen violent weather events during the closure and declared a decrease in gardener and technician teams. Reduced personnel significantly extended the response time and repairs necessary to restore the condition of the garden. The other factor contributing to the deterioration of the condition of the sites was significant changes in the typical schedule of gardening operations. Postponing of such treatments as spring lawn renovation or formative and rejuvenation pruning of shrubs and trees lowered the aesthetic value of the garden. The prioritisation of maintenance operations in gardens closed to the public results in particular in minimisation of the maintenance of the vertical diversity of the garden structure. The leading compromise in this group was a conscious decision not to plant seasonal plants in part or the whole of the garden. Note that a temporary failure to plant seasonal vegetation does not impact the general condition of a historic garden as long as the knowledge on the location, form, and structure of specific compositions survives. A negative aspect related to the maintenance of the vertical structure is the permanent abandonment of topiaries and uncontrolled growth of voluntary seedlings of bushes and trees. This issue was identified in $14 \%$ of the historic gardens, including in those focusing on geometric compositions. In the long term, such an approach will lead to a permanent loss of artistic qualities of the site.

In the context of prioritisation of gardening operations, the respondents indicated prevention of epiphytotic diseases and epizootics. Key maintenance operations carried out by gardeners regardless of the extent of temporary personnel reductions were watering and pest control, including the box tree moth (Cydalima perspectalis).

As regards the trends discussed above, note that regardless of the extent of the horizontal and vertical structure of a garden, a personnel reduction to $99-75 \%$ did not cause a deterioration in its condition, and preserved the historical clarity of the spatial composition. The high-risk range regarding the safety of maintaining a garden in a non-deteriorated condition was the staff reduction intervals to $74-50 \%$ and $49-25 \%$. A reduction to $25-0 \%$ was an immediate and direct threat to the stability regardless of the preparation.

The ranges mentioned above pose a threat to the garden, especially when combined with a lack of a strategic document to indicate the general principles of restoration and parameters for the ongoing maintenance. Only less than half of the managers participating in the survey had such a document, and $24 \%$ were working on it. The threat referred to above is real for $28 \%$ of the sites that did not have the strategic document. Additionally, $69 \%$ of the respondents did not take advantage of other experts in garden management during COVID-19. This demonstrates two facts: their high level of self-reliance but also that they were making intuitive decisions according to the current situation, their knowledge and experience. The response time is worth noting, as well. In over half of the facilities, it took a week to develop and implement an emergency plan after the managers received a notification to close the garden down. 
The general changes in historic gardens caused by the COVID-19 pandemic involved more than just garden compositions, as can be seen from the survey questions. The respondents identified biocoenotic changes in the gardens caused by changes in the availability to the public and intensity of maintenance operations.

Over half of the respondents (59\%) indicated beneficial environmental changes. Four main types of biocoenotic changes emerge from the responses. These are phytocoenotic, zoocoenotic, physicochemical changes in water and air, and other changes. The phytocoenotic changes declared by the respondents were accelerated ecological succession, mostly occurrence of park ground cover species in the vertical structure. Other positive phytocoenotic changes were the stability of designed plant structures that were degraded before due to intensive use by visitors. The phytocoenotic changes are driven by:

- the season when the COVID-19 pandemic broke out,

- a radical drop in attendance,

- limitation of the size of teams dedicated to ongoing maintenance,

- prioritisation of care operations, whereby lawn mowing was most often less frequent.

Beneficent changes in the vertical structure mean generally increased biodiversity of the ground cover and amount to $32 \%$ of the identified changes. Zoocoenotic changes were another type of leading biocoenotic effects. It means not only increased activity and presence of birds, small mammals, deer, wild boar, or insects not seen in the garden for a long time but also an increase in their local populations. The main driver of beneficial zoocoenotic changes in the investigated historic gardens was the closure for safety reasons during the mating and breeding seasons of animals.

The global and local reduction in transport and industry activity had an impact on the ecosystems of historic gardens as well. It was reflected in the responses as a noticeable improvement of physicochemical properties of water and air. Another matter worth mentioning is the effect of a lower rate of mechanical damage caused by high visitor volumes or occasional vandalism. It was beneficial for the stability of both vertical and horizontal structures.

The additional question about the possibilities of maintaining the beneficial biocoenotic changes in the historic gardens made abundantly clear the strong relationship between the attendance and the financial situation of the sites. Restriction of the former could help maintain most of the positive environmental changes, but would also reduce the income necessary for stable management and maintenance. Some respondents declared that positive phytocoenotic changes could be maintained by administrative decisions such as modified lawn mowing schedules.

The gardening staff could continue their work in a relatively normal manner as opposed to other divisions in the complex organisational structures of the gardens, such as finance, conservation, or education. This exhibited their educational potential. Almost $36 \%$ of the respondents indicated that the personnel was not involved in any virtual activity. This situation could have diverse causes, such as the organisation of work and workload of gardeners or the fact that other divisions were responsible for such activities. The auxiliary question regarding the necessity to improve gardening personnel competencies in customer service and virtual activities demonstrated no demand for such an approach. Sixty-nine percent of the respondents believed their teams did not need additional training and only $14 \%$ followed this development path for their employees.

As regards virtual activities, the managers aimed their efforts mostly towards social media ( 25 responses) where they published posts, pictures, and stories to compensate for the temporary unavailability of their gardens. Content analyses demonstrated that the largest reach and activity of social media users were reached by accounts on the current state of the garden (it was the time of spring and early summer in Europe) or content regarding garden history. It is an important insight into the significant potential of the virtual world for information and awareness-raising regarding the existence, character, and value of garden patrimony. Videos and podcasts were less popular (15 responses) followed by virtual tours (12 responses), which was most likely due to technical limitations. 
Some sites expanded their websites (9 responses), shared digital publications (8 responses), and held webinars and online education courses (3 responses). Other solutions included photograph challenges ( 3 responses) that encouraged users to share their photographs online. Note that only two Polish facilities refrained from online activities.

The financial standing of historic gardens provided important insight into the impact of the pandemic. Most of the respondents indicated they suffered significant losses (72\%). Only a small share of the sites recorded minor losses $(4 \%)$ or were not hit by the pandemic financially $(4 \%)$. In their comments, the respondents pointed out that the consequences could be long-term and be felt as late as in the autumn or even in the next season in 2021. The deterioration of the situation of historic gardens will have a lasting effect on their condition and restoration progress. It can be rendered even worst by the second wave of the COVID-19 pandemic and escalating economic crisis, which can turn into the worse global recession in decades according to the World Bank [34]. It is bad news for institutions with entry fees, events, and services for local visitors as the sole source of income because it threatens their stability.

The managers are already taking steps to improve the financial situation. One of them is to reduce personnel and outsourcing costs. The first actions taken by the respondents was to implement redundancy programs ( 7 responses), reduce bonuses ( 7 responses), or reduce base salaries ( 6 responses). They further mentioned that third-party service providers also suffered through contract suspension or termination. The saving schemes to alleviate the financial impact resulted in a complete restriction of hiring and outsourcing (8 responses). Employees of ten historic gardens participating in the survey were not affected financially by COVID-19.

Apart from the reduction in personnel costs, the administrators took other actions to secure additional funding for their gardens. Most of them intensified promotion (14 responses). Some sites expanded their commercial offer for visitors (7 responses) and their educational portfolio (4 responses). The administrators decided to apply for government reimbursement of losses from the pandemic (4 responses), but none addressed NGOs or EU institutions. Other solutions included intensified partner collaboration (private business and institutions), which contributed additional means for garden maintenance (8 responses). As many as nine of the respondents took no action to balance their budgets, all of them state-funded.

\section{Discussion}

The COVID-19 pandemic and the changes it brought inspired many documents with proposed emergency procedures in line with national prevention policies. They focused on the functioning of cities and various domains of everyday life.

One of the general proposals published by the ICOMOS in April 2020 was Urban Function-Spatial Response Strategy for the Epidemic-A Concise Manual on Urban Emergency Management by the Urban Heritage Conservation and Sustainable Development Research Team, School of Architecture, Southeast University (SEU), China SEU Key Laboratory of Urban and Architectural Heritage Conservation, Ministry of Education, China, UNESCO Chair in Cultural Resource Management based on Chinese experience from late 2019 and early 2020. It describes the inability of modern Chinese cities to respond to emergencies. It focused on outlining instructions in accordance with the International Health Regulations (2005), Public health preparedness and response (2018), and the World Health Organisation documents (WHO). It was an attempt to adapt at the micro and macro level, focusing on transport, medical facilities, and spatio-functional adjustments, while disregarding landscape heritage structures [35].

Gardens (historical, botanical, and other) have been considered part of the social life for centuries. It was a popular place of respite and recreation, a haven for those seeking refuge from the hustle and bustle of the city [36]. Visiting a garden is a form of tourism and recreation as the garden is perceived as a place that brings people together [37]. 
In May, a group of researchers conducted analyses of a social-media survey regarding the importance and availability of green sites during the COVID-19 pandemic. The survey spanned four European countries. Its results showed that green areas became a highpriority service of high impact on the health and well-being of the public [38,39]. The authors emphasised the value of urban forests that became the 'critical infrastructure' for the whole urban system $[40,41]$. As regards publications by managers of historic gardens affected by the COVID-19 pandemic, only the European Route of Historic Gardens, an association of 33 historic gardens published on its website a paper reflecting on the situation [42].

Other research demonstrated that contact with nature (gardens) during a COVID19 lockdown reduces the rate of reported depression and anxiety and may shield from a negative impact of a quarantine, protecting the mental and physical health through access to green areas and various forms of activities and recreation [26,43,44]. In addition to international publications, individual countries have various response strategies. In France, Comité des Parcs et Jardins de France published special recommendations Spécial COVID-19-Réouverture et Charte sanitaire for handling public access to gardens and health rules [45]. The country was divided into green and red regions. Gardens in the first zone were opened on 11 May with general safety principles applied. The gardens in the other zone remain closed to the public. Their managers may, however, address their local prefect with a request for a waiver, specifying the date of opening, financial reasons, and measures that would be taken to conform to national safety regulations. La Demeure Historique published similar recommendations for its members, COVID-19: Mesures d'accompagnement et de soutien [46]. It contained a health protection plan and a good safety practice guide.

In the United Kingdom, The Gardens Trust published a short note, The impact of Covid-19 on parks and gardens [47], where it listed the most significant consequences of the pandemic such as cancelled events and suspended volunteer schemes. Greenspace Scotland published a guide, Managing Scotland's parks and greenspaces during COVID-19 [48], with key guidelines for park care, infrastructure maintenance, visitor management and activities, personnel, contractors, and volunteer management, and communication. A similar brochure Managing Public Parks during Covid-19 was published by Community First Partnership with The National Lottery Heritage Fund, Local Government Association, National Trust, Association of Public Service Excellence the Midlands Parks Forum, and mangers of green sites [49]. The Royal Parks introduced a special policy for park-goers such as closed public toilets, sports facilities, and playgrounds until further notice, opening of several catering kiosks for takeaway only, or suspended cycling in Richmond Park [50]. The Fields in Trust published a guide for managers of green areas, Management of green spaces during Covid-19. They do not recommend a complete closure of parks unless absolutely necessary, and no safety measures can be implemented. The recommendations include adaptation of infrastructure and equipment, restoration of staff and volunteer work, opening green areas to visitors, restoration of past activities, and communication [51].

The survey demonstrated a different direction leading to the identification of problems of a specific domain that is historic gardens (museums). The proposed survey approach involving eight European countries provides a broader outlook on problems the research identified. These include the specificity of treatments based on conservation and continuation of restoration schemes. The research shows that $68 \%$ of the curators limited gardening operations to minimise the risk of COVID-19.

This approach stemmed from general safety standards implemented in most green public spaces in Europe. The results indicate that $84 \%$ of the historic gardens implemented special safety measures, such as imposed social distance, obligatory face masks, limited visitor volume, reduced opening hours, and disinfection of benches and other relaxation areas.

The education and promotion aspect, connected to financial matters, was important for historic gardens, as they are different from green public areas. The virtual effort, including social media, videos, podcasts, virtual tours, website expansion, and online publication was noted for $96.5 \%$ of the historic gardens. 
The difficult financial situation contributed to reduced gardening teams (18\%), which may escalate in future. To set off the further financial strain, $81 \%$ of the gardens made an effort to secure funds. The effort involved extra promotion, improved commercial offer, and educational programs.

\section{Conclusions}

The paper complements research on management in a specific group of historic gardens during crises. On the one hand, the survey results demonstrated weaknesses of garden management (restriction of expenses, personnel reductions). On the other hand, they showed personnel management opportunities to improve the chance of controlling damage to the historic green structure of gardens. It proposes promotion approaches that can help improve the financial standing of the gardens. Thirty percent of the respondents pointed out the need to ensure funds to minimise the impact on the condition of historic gardens. Moreover, $22 \%$ of them indicated the need for crisis management, counselling, and training. Twenty-one percent suggested a pandemic manual, and 19\%, a platform for exchanging knowledge and experience.

An outline of procedural recommendations for continued pandemic and other similar emergencies is provided in eight key actions to help protect valuable cultural assets such as historic gardens.

Their value for the global patronage related to the landscape was emphasised in the Florence Charter, which determined the general principles for care and conservation of the designed landscape.

1. An indication of the necessity for every historic site to develop a maintenance policy for a crisis and a management-level document superior to it to determine the general principles and scope of restoration (if applicable) of the garden, taking into account treatment priorities, and set parameters for the number and competencies of the personnel responsible for the ongoing maintenance or smooth restoration together with any machinery necessary,

2. The development of a binding emergency management policy to ensure non-deteriorated conditions of the garden and prioritise care operations following the style of the garden or its part,

3. A recommendation to refrain from redundancy schemes concerning personnel responsible for everyday care, while implementing strict health precautions when facing a situation similar to COVID-19,

4. The extension of professional development schemes for gardeners so that they can co-create statutory content when the activity is shifted to the online environment,

5. The establishment of centres for emergency coordination for historic gardens and cultural landscape with ministries of culture (not only for matters related to a pandemic, but also for epiphytotic diseases and epizootics that directly endanger the stability of historic gardens and their components as well as the negative impact of long-term weather events or ecological crises). Simultaneous provision of funds necessary to continue the ongoing treatments in gardens, including to cover salaries of the personnel and contractors responsible for ongoing operations as well as funds necessary to secure interventions and prevention,

6. An indication to develop financial aid schemes by state administration that would allow:

- the provision of means necessary to continue ongoing care in gardens, including to cover salaries of personnel and contractors responsible for ongoing operations,

- $\quad$ the provision of means necessary to make interventions and take preventive actions when epiphytotic diseases or epizootics are confirmed that threaten the condition of the historic garden or its important part (box tree moth, horse-chestnut leaf miner, Dutch elm disease, Verticillium wilt) and devastating effects of long-term weather conditions (droughts) and ecological crisis (contamination of surface water and groundwater). 
A recommendation to implement maintenance breaks in historic gardens from March to April (one to two months) for positive biocoenotic changes to take place in what is often the only environmental reservoirs in very urbanised areas. A simultaneous recommendation to provide financial reserves (in facilities administered by state or local cultural institutions) to maintain them in this period (or significant visitor number restrictions from March to April).

Specification of the recommended maximum daily visitor numbers for gardens on the UNESCO World Heritage List, historic monuments, and listed monuments to ensure the safety of their spatial composition and individual components.

Prioritisation of maintenance operations limited due to extraordinary situations, focus on key zones of the garden, coordination of relevant actions in accordance with the profile each site and the possibility to close historic gardens to reconstruct plant and animal resources. These recommendations can contribute to the continued good condition of gardens and exploitation of their ecological potential both in historic gardens and large landscape complexes.

Author Contributions: Conceptualization, K.H. and Ł.P.; methodology, K.H. and Ł.P.; software, J.K.; validation, K.H., Ł.P., J.K. and M.W.-M.; formal analysis, K.H. and Ł.P.; investigation, K.H., Ł.P., J.K.; resources, J.K.; data curation, K.H. and Ł.P.; writing-original draft preparation, K.H., Ł.P., J.K. and M.W.-M.; writing-review and editing, K.H. and M.W.-M.; visualization, K.H., Ł.P., J.K. and M.W.-M.; supervision, K.H. and Ł.P.; project administration, K.H.; funding acquisition, K.H. and M.W.-M. All authors haveread read and agreed to the published version of the manuscript.

Funding: This publication has received financial support from the Polish Ministry of Science and Higher Education under subsidy for science for the FA CUT in 2019 and 20 and Environmental engineering, mining, and energy science 030008-D014/KGPiAK/2021.

Institutional Review Board Statement: Not applicable.

Informed Consent Statement: Not applicable.

Data Availability Statement: Survey data are stored according to GDPR requirements on CUT servers.

Acknowledgments: The authors would like to thank the anonymous reviewers for their thorough work with the manuscript and for providing constructive and insightful comments on this paper.

Conflicts of Interest: The authors declare no conflict of interest.

\section{References}

1. Majdecki, L. Ochrona i konserwacja zabytkowych założen ogrodowych; Wydawnictwo Naukowe PWN: Warszawa, Poland, 1993; pp. 18-20.

2. World Heritage List. Available online: http://whc.unesco.org/en/list/ (accessed on 15 August 2020).

3. O'Donnell, P.M. Florence Charter on Historic Gardens (1982). In Encyclopedia of Global Archaeology; Springer Nature: New York, USA, 2014; pp. 2812-2817.

4. Athanasiadou, E. Historic Gardens and Parks Worldwide and in Greece: Principles of Acknowledgement, Conservation, Restoration and Management. Heritage 2019, 2, 2678-2690. [CrossRef]

5. Majdecki, L.; Majdecka-Strzeżek, A. Ochrona i konserwacja zabytkowych założeń ogrodowych. Wydawnictwo Naukowe PWN: Warszawa, Poland, 2019.

6. Carneiro, A.R.S.; da Silva, J.M.; de S. Veras, L.M.; de F. Silva, A. The complexity of historic garden life conservation. Measuring Heritage Conservation Performance at the 6th International Seminar on Urban Conservation, Rome, Italy, 29-31 March 2011; Zancheti, S.M., Similä, K., Eds.; pp. 33-41.

7. Cazzani, A.; Zerbi, C.M.; Brumana, R.; Lobovikov-Katz, A. Raising awareness of the cultural, architectural, and perceptive values of historic gardens and related landscapes: Panoramic cones and multi-temporal data. Appl. Geomatics 2020, 1-34. [CrossRef]

8. Hodor, K. Contemporary threats to historic gardens in Poland. Czas. Tech 2016, 5, 125-143.

9. Tieskens, K.F.; Schulp, C.J.; Levers, C.; Lieskovský, J.; Kuemmerle, T.; Plieninger, T.; Verburg, P.H. Characterizing European cultural landscapes: Accounting for structure, management intensity and value of agricultural and forest landscapes. Land $U_{s e}$ Policy 2017, 62, 29-39. [CrossRef]

10. Schneider, A. Weimarer Hausgärten von der Klassik bis zur Moderne. AHA! Misz, Gartengeschichte Gartendenkmalpfl. 2020, 6, 12-25. [CrossRef] 
11. Benfield, R. Garden Tourism. In The SAGE International Encyclopedia of Travel and Tourism; Lowry, L.L., Ed.; SAGE Publications, Inc: Thousand Oaks, CA, USA, 2017; pp. 165-191.

12. Ahmad, Y. The Scope and Definitionas of Heritage: From Tangible to Intangible. Int. J. Herit. Stud. 2006, 12, 292-300. [CrossRef]

13. Bell, S.; Fox-Kämper, R.; Keshavarz, N.; Benson, M.; Caputo, S.; Noori, S.; Voigt, A. Urban Allotment Gardens in Europe; Routledge: New York, NY, USA, 2016.

14. Hristov, D.; Naumov, N.; Petrova, P. Interpretation in historic gardens: English Heritage perspective. Tour. Rev. 2018, 73, 199-215. [CrossRef]

15. Kuśmierski, J. Hortuseum Musealisation of the European Gardens in the Twenty-First Century; The Sarny Castle Trust: Ścinawka Górna, Poland, 2020.

16. Rohde, M. Historische Gärten Als Kulturaufgabe. In Historische Gärten und Klimawandel; Hüttl, R.F., Karen, D., Schneider, B.U., Eds.; De Gruyter Akademie Forschung: Berlin, Germany, 2020; pp. 31-51. Available online: https://www.degruyter.com/view / book/9783110607772/10.1515/9783110607772-005.xml (accessed on 15 January 2021).

17. Harney, M. Gardens and Landscapes in Historic Building Conservation; Wiley-Blackwell: Chichester, UK, 2014.

18. Qumsiyeh, M.; Handal, E.; Chang, J.; Abualia, K.; Najajrehm, M.; Abusarhan, M. Role of museums and botanical gardens in ecosystem services in developing countries: Case study and outlook. Int. J. Environ. Stud. 2017, 74, 340-350. [CrossRef]

19. Funsten, C.; Borsellino, V.; Schimmenti, E. A Systematic Literature Review of Historic Garden Management and Its Economic Aspects. Sustainability 2020, 12, 10679. [CrossRef]

20. La, V.-P.; Pham, T.-H.; Ho, M.-T.; Nguyen, M.-H.; Nguyen, P.K.-L.; Vuong, T.-T.; Nguyen, H.-K.T.; Tran, T.; Khuc, Q.; Ho, M.-T.; et al. Policy Response, Social Media and Science Journalism for the Sustainability of the Public Health System Amid the COVID-19 Outbreak: The Vietnam Lessons. Sustainability 2020, 12, 2931. [CrossRef]

21. Wen, J.; Kozak, M.; Yang, S.; Liu, F. COVID-19: Potential effects on Chinese citizens' lifestyle and travel. Tour. Rev. 2020. [CrossRef]

22. Allam, Z.; Jones, D.S. Pandemic stricken cities on lockdown. Where are our planning and design professionals [now, then and into the future]? Land Use Policy 2020, 97, 104805. [CrossRef] [PubMed]

23. Carr, A. COVID-19, indigenous peoples and tourism: A view from New Zealand. Tour. Geogr. 2020, 22, 491-502. [CrossRef]

24. Pouso, S.; Borja, Á.; Fleming, L.E.; Gómez-Baggethun, E.; White, M.P.; Uyarra, M.C. Contact with blue-green spaces during the COVID-19 pandemic lockdown beneficial for mental health. Sci. Total. Environ. 2021, 756, 143984. [CrossRef] [PubMed]

25. Kostof, S. The City Assembled -The Elements of Urban Form Through History; Thames \& Hudson: London, UK, 1992.

26. Racon-Leja, K. Miasto i Wojna; Wydawnictwo Politechniki Krakowskiej: Kraków, Poland, 2019.

27. Henderson, J. Disasters without planning: Lessons for museums. Conservator 1995, 19, 52-57. [CrossRef]

28. Caple, C. Presentive Conservation in Museums; Routledge Oxford: Abingdon, UK; p. 2012.

29. Oddy, A.; Keene, S. Managing Conservation in Museums. Stud. Conserv. 1997, 42, 126. [CrossRef]

30. Ferraro, J.; Henderson, J. Identifying Features of Effective Emergency Response Plans. J. Am. Inst. Conserv. 2011, 50, 35-48. [CrossRef]

31. Szmit-Naud, E. Działania z zakresu konserwacji zapobiegawczej: Audyt konserwatorski-metoda i przykłady. Acta Univ. Nicolai Copernici Zabytkozn. Konserw. 2015, 45, 311-334.

32. Przybylak, Ł. Models of implementation and maintenance activities implemented in the Wilanów garden in response to contemporary restoration challenges of historical gardens. Ochr. Zabyt. 2019, 2, 93-119.

33. Karaşah, B.; Var, M. Recreational Functions of Botanical Gardens And Examining Sample of Nezahat Gökyiğit Botanical Garden. Geography 2013, 803-809.

34. World Bank Group, Global Economic Prospects. Available online: https://www.worldbank.org/en/publication/globaleconomic-prospects (accessed on 15 August 2020).

35. ICOMOS International Conservation Center-Xi'an. Available online: https://www.icomos.ch/wp-content/uploads/2020/03/20 200318-ICOMOS-CHINA.pdf (accessed on 15 August 2020).

36. Čakovská, B. Sustainable Garden Tourism in the United Kingdom or What's Behind the Fence? Acta Hortic. Regiotect. 2017, 20, 49-54. [CrossRef]

37. Connell, J. Managing gardens for visitors in Great Britain: A story of continuity and change. Tour. Manag. 2005, 26, 185-201. [CrossRef]

38. Uchiyama, Y.; Kohsaka, R. Access and Use of Green Areas during the COVID-19 Pandemic: Green Infrastructure Management in the "New Normal". Sustainability 2020, 12, 9842. [CrossRef]

39. Xie, J.; Luo, S.; Furuya, K.; Sun, D. Urban Parks as Green Buffers During the COVID-19 Pandemic. Sustainability 2020, $12,6751$. [CrossRef]

40. Derks, J.; Giessen, L.; Winkel, G. COVID-19-induced visitor boom reveals the importance of forests as critical infrastructure. For. Policy Econ. 2020, 118, 102253. [CrossRef]

41. Clearing House H2020. Available online: http:/ / clearinghouseproject.eu/2020/07/23/green-spaces-urban-forests-during-thecovid-19-pandemic/ (accessed on 15 August 2020).

42. European Route of Historic Gardens, Historic Gardens and COVID-19: Times for reflection and action. Available online: http:/ / europeanhistoricgardens.eu/en/historic-gardens-context-covid19-reflection-action/ (accessed on 15 August 2020). 
43. Dzhambov, A.M.; Lercher, P.; Browning, M.H.E.M.; Stoyanov, D.; Petrova, N.; Novakov, S.; Dimitrova, D.D. Does greenery experienced indoors and outdoors provide an escape and support mental health during the COVID-19 quarantine? Environ. Res. 2020, 110420. [CrossRef]

44. Szopińska, E.; Kazak, J.; Kempa, O.; Rubaszek, J. Spatial Form of Greenery in Strategic Environmental Management in the Context of Urban Adaptation to Climate Change. Pol. J. Environ. Stud. 2019, 28, 2845-2856.

45. Comité des Parcs et Jardins de France, Spécial COVID-19 - Réouverture et Charte sanitaire. Available online: https://www. parcsetjardins.fr/actualites / manifestations-nationales/special-covid-19-reouverture-et-charte-sanitaire-1657 (accessed on 15 August 2020).

46. La Demeure Historique, COVID-19: Mesures d'accompagnement et de soutien. Available online: https://www.demeurehistorique.org/divers/mesures-daccompagnement-et-de-soutien/ (accessed on 15 August 2020).

47. The Gardens Trust, The impact of Covid-19 on parks and gardens. Available online: http://thegardenstrust.org/the-impact-ofcovid-19-on-parks-and-gardens / (accessed on 15 August 2020).

48. Greenspace Scotland, Managing parks and greenspaces during Covid-19. Available online: https://www.greenspacescotland. org.uk/pages/category/covid-19 (accessed on 15 August 2020).

49. Community First Partnership (CFP). Managing Public Parks during Covid-19. Available online: http:/ / www.cfpuk.co.uk/wpcontent/uploads/Managing-Public-Parks-During-COVID-19-FINAL-v7.1.pdf (accessed on 15 August 2020).

50. The Royal Parks, The Royal Parks welcomes visitors but warns it's not 'business as usual'. Available online: https://www. royalparks.org.uk/media-centre/press-releases/the-royal-parks-welcomes-visitors-but-warns-its-not-business-as-usual (accessed on 15 August 2020).

51. Fields in Trust, Management of green spaces during Covid-19. Available online: http://www.fieldsintrust.org/knowledge-base/ management-of-green-spaces-during-covid-19 (accessed on 15 August 2020). 